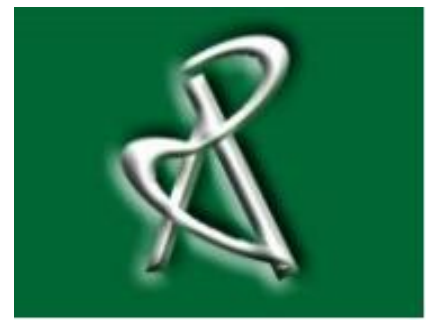

Available online at www.academicpaper.org

Academic @ Paper

ISSN 2146-9067

International Journal of Automotive Engineering and Technologies

Vol. 5, Issue 1, pp. $1-7,2016$

http://www.academicpaper.org index.php/IJAET

\title{
Influence of Diesel Fuel and Soybean Oil Ethyl Ester Blends on the Performance and Emission Characteristics of a Diesel Engine
}

Banu Sugözü*

Institute of Natural and Applied Sciences, Selcuk University, Konya, Turkey

Received 17 November 2015 Accepted 22 February 2016

\begin{abstract}
In this study, blends of soybean oil ethyl ester (SOEE) and diesel fuel are tested as alternative fuel in a single cylinder, air cooled pre-combustion chamber diesel engine at different speeds and their effects on engine performance and emissions are analyzed. It is observed that the average moment obtained by $5 \%$ SOEE (B5) is $0.53 \%$ lower, the level of power obtained is $1.8 \%$ lower; however, specific fuel consumption is approximately $4.31 \%$ higher than those of diesel fuel. In the experiments conducted with $20 \%$ SOEE (B20), it is observed that the average moment is $1.74 \%$ lower, the level of power obtained is $5.91 \%$ lower; however, specific fuel consumption is approximately $10.94 \%$ higher than those of diesel fuel. Moreover, while a distinctive decrease is observed in $\mathrm{CO}$ emissions of fuel blends, NOx emissions are obtained very close to that of diesel fuel.
\end{abstract}

Keywords: Biodiesel, Soybean Oil Ethyl Ester, Alternative Fuels, Engine Performance, Emission

doi: 10.18245/ijaet.47076

*Corresponding Author:

E-mail: banusugozu@gmail.com 


\section{Introduction}

The interest of using alternative and renewable fuels in diesel engines has been accelerated recently due to a rapid decrease in world petroleum reserves, increase in the prices of the conventional petroleum fuels and restrictions on exhaust emissions from internal combustion (IC) engines triggered by environmental concerns. Nowadays, many countries are replacing their conventional energy sources with renewable and sustainable ones in some extent [1]. Among these fuels, alcohols can be used as either blends with the conventional fuels in the existing engines or an additive in biodiesel production [2], have received increasing attention. Because of their higher octane number and oxygen content, combustion of alcohols in spark ignition (SI) engines show better results compared to gasoline [3]. However, it has been reported as a significant matter that there have been some difficulties in the ignition of the airfuel mixture with the use of alcohols in compression ignition (CI) engines owing to mainly their low cetane number, high latent heat of vaporization and long ignition delay [3]. In order to overcome these problems and use alcohol in CI engines, different methods: namely alcohol fumigation, dual injection, alcohol-diesel fuel blend and alcohol diesel fuel emulsion, can be employed [4,5]. It was reported that the use of alcohol-diesel fuel blends in diesel engines extend ignition delay period of the combustion process [6,7]. This period depends on the kind of alcohol blended and becomes longer as the content of the alcohol in the blends is increased. However, the use of alcohol as blend with diesel fuel provides significant improvement in the exhaust emissions [7,8]. Biodiesel is produced from the transesterification of vegetable oils or animal fats and is defined chemically as simple monoalkyl esters (typically methyl or ethyl) of long chain fatty acids that meet the ASTM D6751 [9] or EN 14214 [10] biodiesel standards. The advantages of biodiesel over conventional petroleum diesel fuels include superior lubricity, derivation from renewable sources, essentially no sulfur content, superior flash point and biodegradability, as well as a reduction in most regulated exhaust emissions [11].The objective of this study is to investigate the effects of soybean oil ethyl ester-diesel fuel blends on the diesel engine performance and exhaust emissions. For this aim, two blends containing 5\% (B5) and 20\% (B20) SOEE and were prepared and tested in a diesel engine. Then, the test results of blends were compared with the results of diesel fuel.

\section{Materials and Method}

Engine tests were conducted on a single cylinder and direct-injection (DI) diesel engine. The main specifications of the test engine are given in Table 1. In order to determine the engine torque, the shaft of the test engine was coupled to an electric dynamometer, which was loaded by an electric resistance. A strain load sensor was employed to determine the load on the dynamometer. The engine speed was measured by an electromagnetic speed sensor installed on the dynamometer. The fuel consumption rate of the engine was determined with a weighing scale having a sensitivity of $0.1 \mathrm{~g}$ and an electronic chronometer having a sensitivity of $0.1 \mathrm{~s}$.

\begin{tabular}{|c|c|}
\hline Items & Specifications \\
\hline Cylinders number & 1 \\
\hline Swept volume & $668 \mathrm{~cm}^{3}$ \\
\hline Bore & $90 \mathrm{~mm}$ \\
\hline Stroke & $105 \mathrm{~mm}$ \\
\hline Compression ratio & $21 / 1$ \\
\hline Maximum speed & $3000 \mathrm{~min}^{-1}$ \\
\hline Maximum brake torque & $36.7 \mathrm{Nm}$ at $1800 \mathrm{~min}^{-1}$ \\
\hline Cooling system & Air-cooled \\
\hline
\end{tabular}

The soybean oil ethyl ester used in the study produced in the following manner. 100 gr. vegetable oil, 20 gr. ethanol and $5 \mathrm{gr}$. sulfuric acid mixed and heat at $65-80{ }^{\circ} \mathrm{C}$ for $2-5$ hours. Ethanol was used as an alcohol and sulfuric acid was preferred as a catalyst in this process. A flow diagram of the biodiesel production from soybean oil process is shown in Fig. 1. As shown in figure, soybean oil, after filtering, washing and drying process subjected to esterification reaction 
with an acid catalyst and ethanol. After the esterification reaction, water and catalyst were separated and biodiesel was obtained as a result.

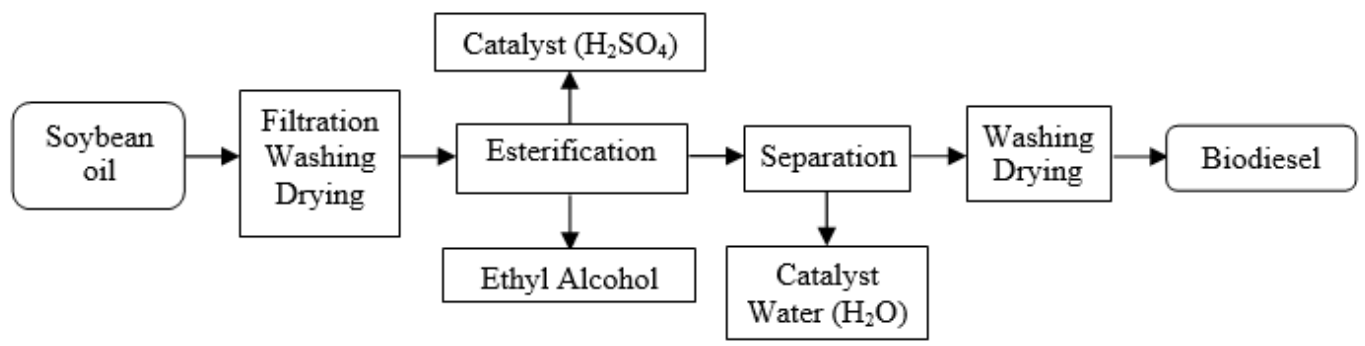

Figure 1. Flow diagram of biodiesel production from soybean oil

Two blending fuels were prepared in volume and employed in the experiments along with pure diesel fuel. The blends were $95 \%$ diesel fuel and 5\% (B5) SOEE and 80\% diesel fuel and $20 \%$ (B20) SOEE. Just before each experiment, the blend was stirred well with an electric mixer until a homogeneous mixture was obtained. It was observed that SOEE blends easily with diesel fuel and the blend maintains its homogeneity for a long time. Diesel fuel was obtained commercially from a local petroleum company and employed in the experiments as base fuel. The physical and chemical properties of the diesel fuel and its blends with SOEE are listed in Table 2.

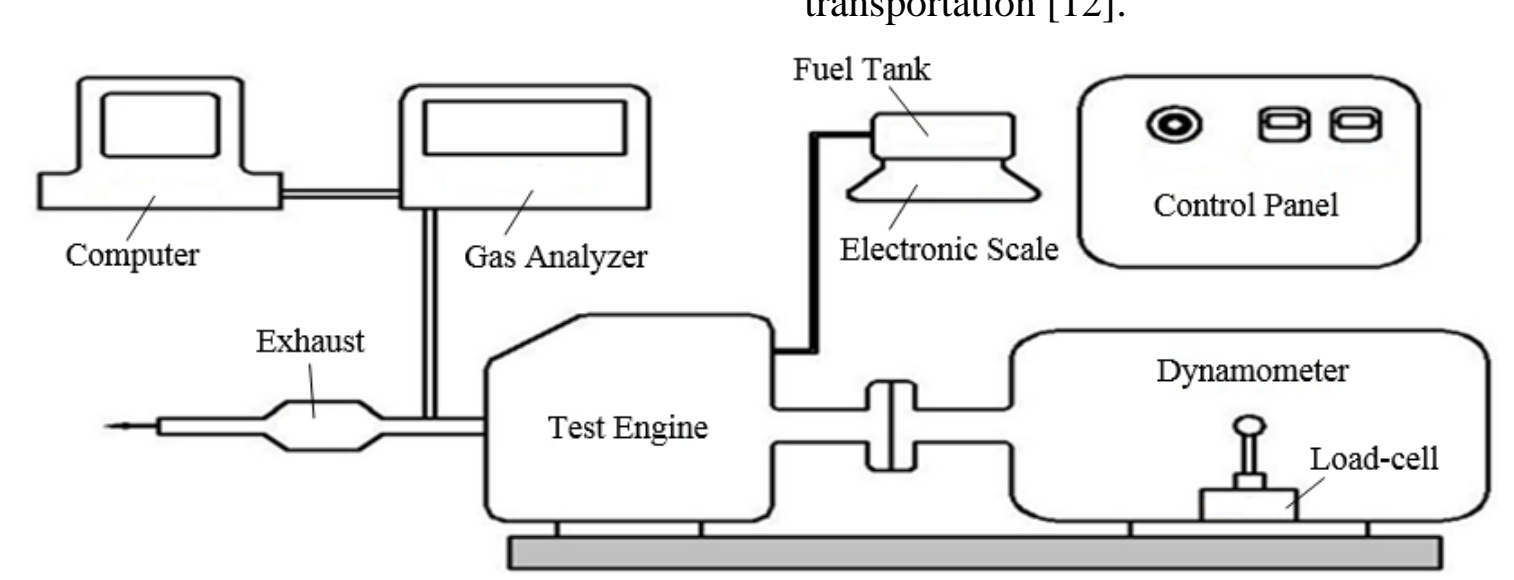

Figure 2. Schematic diagram of experimental set-up

\begin{tabular}{llll}
\hline Table 2. Characteristics of biodiesel and diesel fuel \\
\hline Properties & $\begin{array}{l}\text { Diesel } \\
\text { Fuel }\end{array}$ & B5 & B20 \\
\hline $\begin{array}{l}\text { Density }\left(\mathrm{kg} / \mathrm{m}^{3}\right) \\
\text { Viscosity }\left(\mathrm{mm}^{2} / \mathrm{s}\right)\end{array}$ & 837.6 & 843.2 & 851.3 \\
$\begin{array}{l}\left(\text { at } 40^{\circ} \mathrm{C}\right) \\
\text { Flash Point }\left({ }^{\circ} \mathrm{C}\right)\end{array}$ & 61.60 & 4.66 & 4.74 \\
$\begin{array}{l}\text { Calorific Value } \\
(\mathrm{kJ} / \mathrm{kg})\end{array}$ & 44980 & 63.2 & 65.4 \\
\hline
\end{tabular}

Diesel fuel and diesel-biodiesel blends specifications have been determined according to EN 14214 standards. The viscosity of biodiesel is higher than diesel fuel. The flash point of biodiesel is higher than diesel fuel. The biodiesel, high flash point makes possible its easy storage and transportation [12].
To determine the performance and emission characteristics of test fuels, engine was risen to the maximum speed can reach and the hydraulic dynamometer has begun to be installed. All tests were performed at fullload conditions and the engine speed were changed between 1400 and $2200 \mathrm{~min}^{-1}$ with intervals of $200 \mathrm{~min}^{-1}$. After each fuel test, the engine was operated for at least $30 \mathrm{~min}$ to consume the fuel which was left in the fuel system from the previous test. Each of test fuels tested three times and the average of the measured values were taken. The engine power, torque and specific fuel consumption were measured at the engine performance tests while the carbon monoxide (CO) and nitrogen oxides $\left(\mathrm{NO}_{\mathrm{x}}\right)$ were determined at the engine emissions tests. Measurement of $\mathrm{CO}$ 
and $\mathrm{NO}_{\mathrm{X}}$ exhaust emissions is realized utilizing a Testo 350 XL branded portable gas analysis device. Schematic drawing of engine test mechanism is given in Fig. 2.

Mixtures of SOEE and diesel fuel (D2) were evaluated as test fuels. These fuels were $100 \%$ D2, 5\% SOEE-95\% D2, 20\% SOEE$80 \%$ D2. Test fuels were mixed on a volume basis.

\section{Results and Discussion}

\subsection{Engine performance}

Fig. 3 shows the influence of different SOEE-diesel blend fuels on engine torque. The use of biodiesel blended with diesel caused a slightly decrease in engine torque at all engine speeds. Maximum torque was measured at $1800 \mathrm{~min}^{-1}$ for all fuels. At this speed, maximum torque was obtained 36.16 $\mathrm{Nm}$ for diesel fuel, $35.89 \mathrm{Nm}$ for B5, 35.63 $\mathrm{Nm}$ for B20. Compared to diesel fuel, the maximum decrease in torque was $2.94 \%$ with B20 in $2200 \mathrm{~min}^{-1}$. Similar results were reported by other investigator $[13,14,15]$.

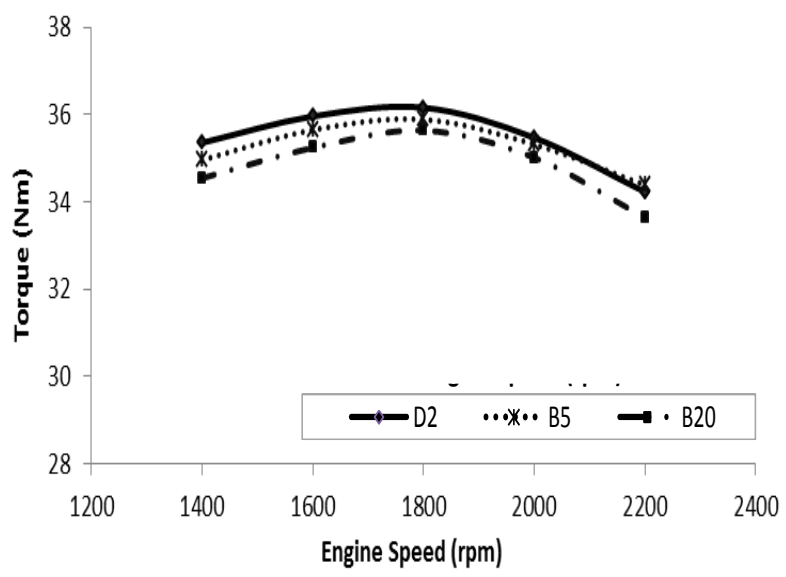

Figure 3. Engine torque at full load

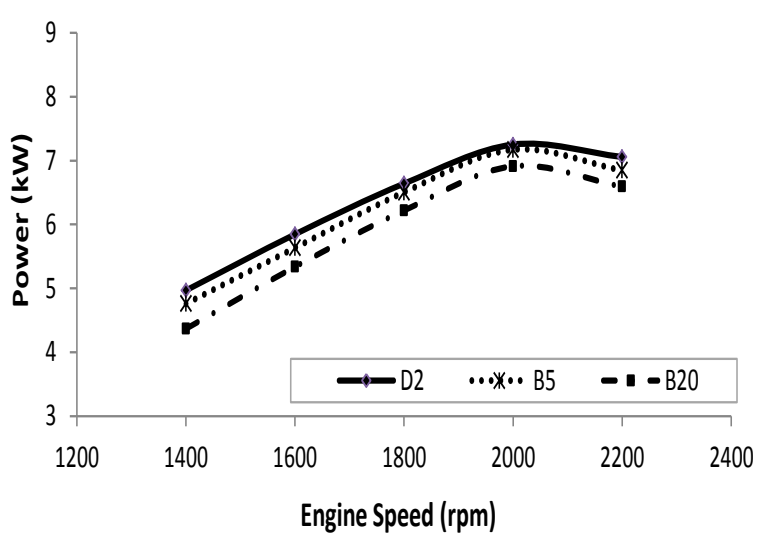

Figure 4. Engine power at full load
The changes in engine power are shown in Fig. 4. Calculated power for diesel fuel is $6.64 \mathrm{~kW}$ at $1800 \mathrm{~min}^{-1}$ and $6.50 \mathrm{~kW}$ for B5, $6.21 \mathrm{~kW}$ for B20. The lower calorific value of biodiesel is the main reason for decrease in engine power and torque. Despite the slightly decrease in engine torque and power, one can say that the engine power and torque characteristics of blended fuels are similar to pure diesel fuel. Compared to diesel fuel, the specific fuel consumption values of SOEE were higher in general (Fig. 5). This is probably because of the lower calorific value of biodiesel fuel. The lowest specific fuel consumption values were obtained at 1800 $\min ^{-1}$ with all test fuels while the highest specific fuel consumption values were obtained at $1400 \mathrm{~min}^{-1}$. The maximum decrease in specific fuel consumption was $3.84 \%$ with B5 in $1800 \mathrm{~min}^{-1}$. These results are similar to study of other researchers $[16,17,18]$.

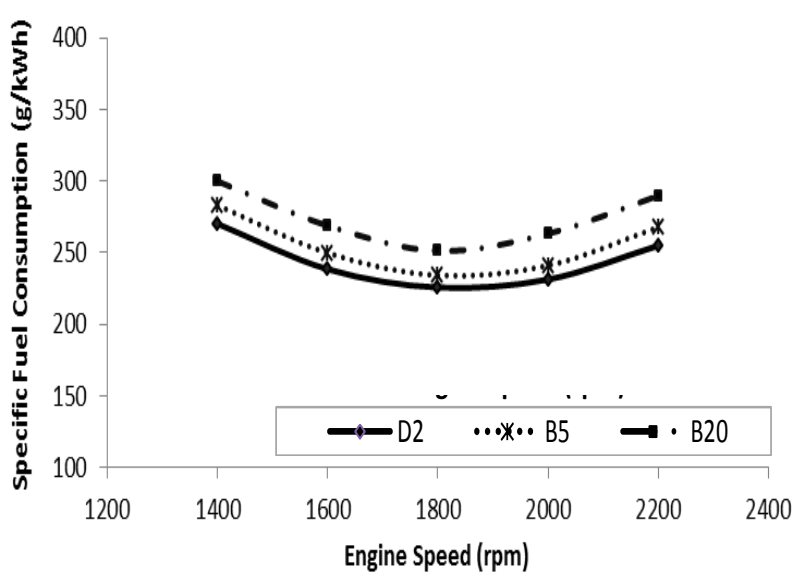

Figure 5.Specific fuel consumption at full load

\subsection{Engine emission results}

$\mathrm{CO}$, formed by the incomplete combustion of fuels, is produced most readily from petroleum based fuels, which contain no oxygen in their molecular structure $[19,20$, 21, 22]. As seen in Fig. 6, lower CO emission values were measured with SOEE blends in comparison with diesel fuel. The maximum decrease in $\mathrm{CO}$ emission was $36.21 \%$ with $\mathrm{B} 20$ in $1800 \mathrm{~min}^{-1}$ while the minimum $\mathrm{CO}$ emission was 675 ppm with B20 in $2200 \mathrm{~min}^{-}$ ${ }^{1}$. CO emission values in maximum torques $\left(1800 \mathrm{~min}^{-1}\right)$ are $1066 \mathrm{ppm}$ for diesel fuel, $1006 \mathrm{ppm}$ for B5, $680 \mathrm{ppm}$ for B20. The 
reduction in $\mathrm{CO}$ emission with blended fuels is due to the fact that the oxygen content in the blended fuels increases the oxygen-tofuel ratio in the fuel-rich regions and helps for the complete combustion [23, 24, 25, and 26].

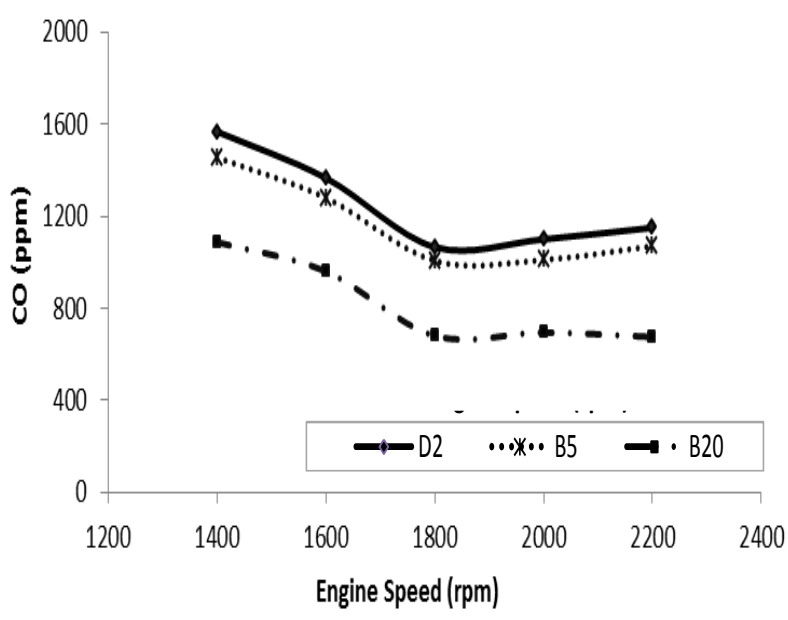

Figure 6. CO emissions at full load

Considering the $\mathrm{NO}_{\mathrm{x}}$ emission, Fig. 7 shows that the $\mathrm{NO}_{\mathrm{x}}$ concentration is higher when SOEE percentage increases. The highest $\mathrm{NO}_{x}$ emission values were obtained with all fuel blends between 1600 and $1800 \mathrm{~min}^{-1}$ engine speeds. The maximum $\mathrm{NO}_{\mathrm{x}}$ emission values for all fuels were measured in $1800 \mathrm{~min}^{-1}$ as $560 \mathrm{ppm}$ for diesel fuel, $600 \mathrm{ppm}$ for B5, 643 ppm for B20. There are several reported results of slight increase in $\mathrm{NO}_{\mathrm{x}}$ emissions for biodiesel [27, 28, and 29].

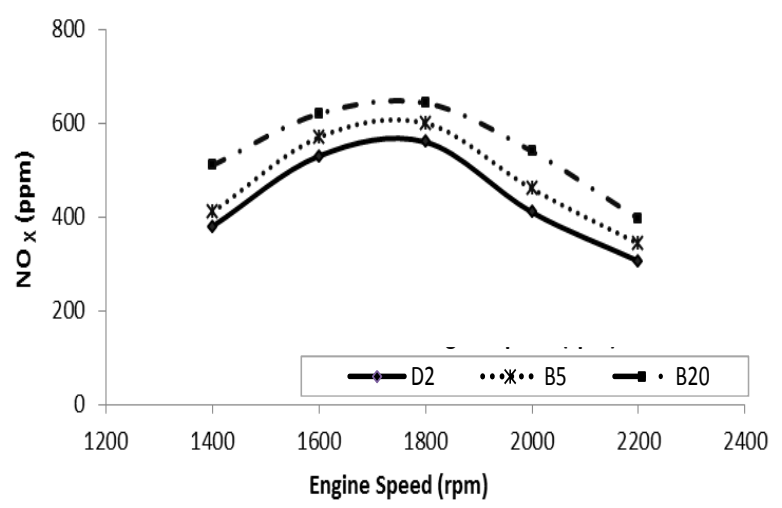

Figure 7. NOx emissions at full load

It is quite obvious, that with biodiesel, due to improved combustion, the temperature in the combustion chamber can be expected to be higher and higher amount of oxygen is also present, leading to formation of higher quantity of NOx in biodiesel-fueled engines.
Nevertheless, in some studies, no change or decrease is observed in the amount of $\mathrm{NO}_{\mathrm{x}}$ emissions [30, 31, and 32]. At this point, the importance of engine test circumstances (such as engine speed and load) arises. Since the specific fuel consumption of biodiesel is higher than diesel fuel and the oxygen in biodiesel provide sufficient oxygen in the fuel-rich regions, the number of full burning (Stoichiometric) regions increase. Thus and so the number of regions where high temperatures are obtained increases, nitrogen oxide formation is realized at higher levels.

\section{Conclusions}

Blended fuels can be used as alternative fuels in conventional diesel engines without any major modification. Low sulphur and aromatic contents are advantages of SOEEdiesel fuel blends. No significant problem is observed in the engine parts during and after the experiments. There were no significant torque and power differences between the D2 and biodiesel (blended fuels) at all engine speeds. At all engine speeds, specific fuel consumption increased with blended fuels depending on the amount of soybean oil ethyl ester. But, relative to diesel fuel, specific fuel consumption for blended fuels did not increase significantly at higher engine speeds. Soybean oil ethyl ester-diesel fuel blends had the advantages of decreasing $\mathrm{CO}$ emissions, low sulphur content and higher cetane number.

\section{References}

[1] Demirbas, A., "Energy balance, energy sources, energy policy, future developments and energy investments in Turkey", Energy Conversion and Management, 42, 10, pp. 1239-1258, 2001.

[2] Karabektas, M., Ergen, G., Hosoz, M., "The effects of preheated cottonseed oil methyl ester on the performance and exhaust emissions of a diesel engine", Applied Thermal Engineering 28, 17-18, pp. 21362143, 2008.

[3] Saeed, M. N., Henein, N.A., "Combustion phenomena of alcohols in C. I. engines", Journal of Engineering for Gas Turbines and Power, 111, 3, pp. 439-444, 1989. 
[4] Can, O., Çelikten, İ., Usta, N., "Effects of ethanol addition on performance and emissions of a turbocharged indirect injection diesel engine running at different injection pressures", Energy Conversion and Management, 45, 15-16, pp. 2429-2440, 2004.

[5] Abu-Quadis, M., Haddad, O., Qudaisat, M., "The effect of alcohol fumigation on diesel engine performance and emissions", Energy Conversion and Management, 41, pp.389-99, 2000.

[6] Czerwinski, J., "Performance Of HD-DI Diesel Engine With Addition Of Ethanol And Rapeseed Oil", SAE Paper No. 940545, 1994.

[7] Hansen, A.C., Zhang, Q., Lyne, P.W.L., "Ethanol-diesel fuel blends-a review", Bioresource Technology, 96, 3, pp. 277-285, 2005.

[8] Sendzikiene, E., Makareviciene, V., Janulis, P., "Influence of fuel oxygen content on diesel engine exhaust emissions", Renewable Energy, 31, 15, pp. 2505-2512, 2006.

[9] American Society for Testing Materials (ASTM) D975-96, Standard Specification for Fuel Oils, Annual Book of ASTM Standards; Philadelphia, USA, 1997.

[10] European Committee for Standardization, EN 14214, Automotive fuels-fatty acid methyl esters (FAME) for diesel engines-requirement methods, Brussels (Belgium), 2003.

[11] Knothe, G., Krahl, J., Van Gerpen, J., "The biodiesel handbook", Champaign, IL (USA): AOCS Press, 2005.

[12] Shadid, E. M., Jamal, Y., "A review of biodiesel as vehicular fuel" Renewable and Sustainable Energy Reviews, 12, 9, pp.24842494, 2008.

[13] Ozsezen, A., Canakci, M., Turkcan, A., Sayin, C., "Performance and combustion characteristics of a DI diesel engine fueled with waste palm oil and canola oil methyl esters", Fuel, 88, 4, pp. 629-636, 2009.

[14] Keskin, A., Gürü, M., Altiparmak, D., Aydin, K., "Using of cotton oil soapstock biodiesel-diesel fuel blends as an alternative diesel fuel", Renewable Energy 33, 4, pp.
553-557, 2008.

[15] Çetinkaya, M., Ulusoy, Y., Tekin, Y., Karaosmanoğlu, F., "Engine and winter road test performances of used cooking oil originated biodiesel", Energy Conversion and Management, 46, 7-8, pp. 1279-1291, 2005.

[16] Altıparmak, D., Keskin, A., Koca, A., Gürü, M., "Alternative fuel properties of tall oil fatty acid methyl ester-diesel fuel blends", Bioresource Technology, 98, 2, pp. 241-246, 2007.

[17] Gürü, M., Koca, A., Can, Ö., Çınar, C., Şahin, F., "Biodiesel production from waste chicken fat based sources and evaluation with $\mathrm{Mg}$ based additive in a Diesel engine", Renewable Energy, 35, 3, pp. 637-643, 2010. [18] Kalligeros, S., Zannikos, F., Stournas, S., Lois, E., Anastopoulos, G., Teas, C., Sakellaropoulos F., "An investigation of using biodiesel/marine diesel blends on the performance of a stationary diesel engine", Biomass and Bioenergy, 24, 2, pp. 141-149, 2003.

[19] Agarwal, A. K., "Biofuels (alcohols and biodiesel) applications as fuels for Internal Combustion Engines", Progress in Energy and Combustion Science, 33, 3, pp. 233-271, 2007.

[20] Keskin, A., Emiroglu, A. O.," Catalytic reduction techniques for post-combustion diesel engine exhaust emissions", Energy Education Science and Technology Part A: Energy Science and Research, 25, pp. 87$103,2010$.

[21] Ozgur, T., Tuccar, G., Ozcanli, M., Aydin, K., "Prediction of emissions of a diesel engine fueled with soybean biodiesel using artificial neural networks, Energy Education Science and Technology Part A: Energy Science and Research, 27, pp. 301312, 2011.

[22] Çelik, M. B., Şimşek, D., "The Determination Of Optimum Injection Pressure In An Engine Fuelled With Soybean Biodiesel/Diesel Blend", Thermal Science, 2013.

DOI Reference 10.2298/TSCI120807023C. [23] Qi, D. H., Chen, H., Geng, L. M., Bian, Y. Z., Ren, X. C., "Performance and 
combustion characteristics of biodieseldiesel-methanol blend fuelled engine", Applied Energy, 87, 5, pp. 1679-1686, 2010. [24] Upadrasta-Satya, V. P., Kotha, M. M., Gaddale, A. P. R., "Effective Utilization Of B20 Blend With Oxygenated Additives", Thermal Science, 15, 4, pp. 1175-1184, 2011.

[25] Yucel, Y., Tekeli, Y., "Biodiesel production from canola oil using immobilized lipase", Energy Education Science and Technology Part A, 27, pp. 337346, 2011.

[26] Krishnakumar, J., Venkatachalapathy, K. V., Elancheliyan, S., "Technical Aspects of Biodiesel Production from Vegetable Oils", Thermal Science, 12, 2, pp. 159-169, 2008.

[27] Çanakçı, M., "Production of biodiesel from feedstocks with high free fatty acids and its effect on diesel engine performance and emissions", Ph.D. thesis, Iowa State Universty, Ames-Iowa, 2001.

[28 Lapuerta, M., Armas, O., RodriguezFernandez, J., "Effect of biodiesel fuels on diesel engine emissions", Progress in Energy and Combustion Science, 34, 2, pp. 198-223, 2008.

[29] Lin, L., Ying, D., Chaitep, S., Vittayapadung, S., "Biodiesel production from crude rice bran oil and properties as fuel", Applied Energy, 86, 5, pp. 681-688, 2009.

[30] Canakci, M., Van, G. J. H., "Comparison of engine performance and emissions for petroleum diesel fuel, yellow grease biodiesel, and soybean oil biodiesel", Transactions of the ASAE, 46, pp. 937-944, 2003.

[31] McDonald, J. F., Purcell, D. L., McClure, B. T., Kittelson, D. B., "Emissions Characteristics of Soy Methyl Ester Fuels in an IDI Compression Ignition Engine", SAE paper, No.950400, 1995.

[32] Peterson, C. L., Reece, D. L., Thompson, J. C., Beck, S. M., Chase, C., "Ethyl Ester of Rapeseed Used as a Biodiesel Fuel-A Case Study", Biomass and Bioenergy, 10, 5-6, pp. 331-336, 1996. 